\title{
Impacts of conventional and unconventional US monetary policies on global financial markets
}

\section{Shigeki Ono ${ }^{1}$}

Published online: 26 November 2019

(C) The Author(s) 2019

\begin{abstract}
This paper investigates the impacts of conventional and unconventional US monetary policies on global financial markets, using the global vector autoregressive (GVAR) model from 2004 through 2017. The impulse response results suggest unconventional easing had little effect on stock prices as in conventional easing while the responses of interest rates indicate liquidity was provided throughout the world. An unconventional US monetary tightening policy shock could effectively affect the stock prices of the world as is the case with a conventional US monetary tightening shock. Furthermore, the transmission of a US monetary policy shock to stock prices via exchange rates tends to attenuate the decrease in stock prices both in the conventional and unconventional tightening (the exit from a zero rate) phases. On the other hand, the transmission tends to push down stock prices in the conventional, unconventional monetary easing and the unconventional tightening (the shadow rate is negative) phases.
\end{abstract}

Keywords Global VAR · Unconventional monetary policy · Shadow rates · Financial markets

JEL classification $\mathrm{E} 44 \cdot \mathrm{E} 52 \cdot \mathrm{E} 58 \cdot \mathrm{F} 42$

\section{Introduction}

This paper investigates the impacts of conventional and unconventional US monetary policies on global financial markets. With the backdrop of the global financial crisis, the Federal Reserve (Fed) introduced a sequence of unconventional monetary policy measures in late 2008 to provide liquidity through its asset purchase program. The Fed started to taper the aggressive bond-buying program by ten billion US dollars a month

Shigeki Ono

s-ono@live.asahikawa-u.ac.jp

1 Asahikawa University, 3-23-1-9, Nagayama, Asahikawa City, Hokkaido 079-8501, Japan 
in January 2014 and ended its historic easing stimulus program in October 2014. In December 2015, it announced the first rise in US interest rates since 2006.

These policy measures implemented by the Fed could influence financial markets around the world. According to Neely (2013), the Fed's asset purchases had substantial international effects on bond and foreign exchange markets. Large-scale asset purchases influence international asset prices as well because of global capital market linkages.

Several studies have investigated the international spillovers of unconventional US monetary policy on other countries. Ahmed and Zlate (2014) find no statistically significant positive effects of unconventional US monetary expansion on total net emerging market economy inflows whereas Anaya et al. (2017), Barroso et al. (2016), Fratzscher et al. (2017) and Tillmann, 2016) find significant capital inflows outside the US. On the other hand, Gambacorta et al. (2014) find that the estimated output effects are qualitatively similar to those of conventional monetary policy while Hajek and Horvath (2018) find that the effects of unconventional monetary policy measures are weaker than those of conventional measures. Chen et al. (2016) and Georgiadis (2016) claim that the effects from the impact of US quantitative easing are larger outside the US than those in the US. Moreover, Bowman et al. (2015) and Hausman and Wongswan (2011) deal with the effects of US monetary policy announcements to determine significant responses.

This paper examines whether the spillovers of unconventional US monetary policies to global financial markets are different from those of conventional policies, using the global VAR (GVAR) model. Furthermore, this paper also investigates what role exchange rates play as a transmission channel of a US monetary policy shock to stock prices. Specifically, the contributions of the study to the existing literature are as follows:

First, this paper demonstrates the effects of a US monetary policy shock during relatively short periods, using weekly data. ${ }^{1}$ Most studies, using monthly or quarterly data, cannot estimate monetary policy shock effects for a short period because of the insufficient number of samples. ${ }^{2}$ This paper examines the impacts of a US monetary policy shock, including in the conventional monetary easing phase from the beginning of 2007 through mid-2008. Whereas Chudik and Fratzscher (2011) employ weekly data in the GVAR model and analyze the role that the tightening in liquidity conditions and the collapse in risk appetite played in the global transmission of the financial crisis, this paper compares the spillovers of conventional and unconventional US monetary policies in the tightening and easing phases.

Second, shadow interest rates for the US, the UK, the euro area and Japan provided by Krippner (2016) are used in the estimations in order to assess the effects of quantitative easing monetary policy. Whereas Dees et al. (2007), Eickmeier and Ng (2015) and Martin and Cuaresma (2017) use short-term and long-term interest rates, Ganelli and Tawk (2016) use the increase in equity prices and the increase in the monetary base as two alternative proxies of Japan's quantitative and qualitative monetary easing. It would be difficult to compare the effects of conventional monetary

\footnotetext{
${ }^{1}$ This paper does not use daily data in order to cope with the problems of time differences.

${ }^{2}$ Rogers et al. (2014) and Tillmann (2016) use intradaily data to analyze the impacts from the US quantitative easing. However, high frequency data are not appropriate when data of longer than one year are analyzed.
} 
policy with those of unconventional monetary policy, in which short-term interests are at zero or near-zero. Taking into account the advantage of using shadow interest rates, that they are applicable whether the federal funds rate and other policy rates are at zero or not, this paper uses the daily shadow federal funds rates calculated by Krippner (2016) whereas Hajek and Horvath (2018) use the shadow federal funds rates proposed by $\mathrm{Wu}$ and Xia (2016), whose frequency is monthly.

Third, the asymmetric effects of monetary easing and tightening policies are investigated. Furthermore, the differences of effects in conventional and unconventional monetary policies are also examined. Whereas Rogers et al. (2014) discuss a surprise monetary policy of easing and tightening, and Hajek and Horvath (2018) compare the effects of unconventional easing monetary policy measures with those of conventional methods, this paper is characterized by the introduction of five subperiods in the analysis of policy effects. Moreover, this paper divides the unconventional tightening phase into two: one in which the US shadow federal funds rate is negative, and the other in which the federal funds rate is no longer at the zero lower bound. Because no other studies have comprehensively compared conventional and unconventional as well as tightening and easing phases yet, including these two tightening phases, this paper presents differences among them in responses to a monetary policy shock.

Fourth, the role of foreign exchange rates as a transmission channel of a US monetary policy shock to stock prices is accessed by counterfactual analysis. Chen et al. (2016) design counterfactual scenarios in which US QE measures are assumed to be absent whereas Anaya et al. (2017) investigate portfolio flows as a channel of shock transmission, conducting a counterfactual exercise. However, no former studies have focused on foreign exchange rates as a transmission channel in the GVAR framework. This paper presents the changing roles of foreign exchange rates as a transmission channel in accordance with various US monetary policy phases.

The remainder of this paper is organized as follows. Section 2 describes the global vector autoregressive model and identification. Section 3 presents data and a model setup. Section 4 demonstrates empirical results. Section 5 conducts counterfactual analysis. The last section concludes the paper.

\section{The global vector autoregressive model and identification}

This paper employs the global vector autoregression (GVAR), suggested by Pesaran et al. (2004). This model can estimate the impacts of a US monetary policy shock on the global financial markets. A GVAR model is composed on the basis of each country's VARX models. ${ }^{3}$ The VARX $\left(p_{i}, q_{i}\right)$ model for country $i(i=0, \cdots, N)$ can be expressed as follows:

$$
\boldsymbol{\Phi}_{i}\left(L, p_{i}\right) \boldsymbol{x}_{i, t}=\boldsymbol{a}_{i, 0}+\boldsymbol{a}_{i, 1} t+\boldsymbol{\Lambda}_{i}\left(L, q_{i}\right) \boldsymbol{x}_{i, t}^{*}+\boldsymbol{u}_{i, t},
$$

where $\boldsymbol{x}_{i, t}$ is a $k_{i} \times 1$ vector of endogenous variables, $\boldsymbol{x}_{i, t}^{*}$ is a $k_{i}^{*} \times 1$ vector of foreign variables, $\boldsymbol{\Phi}_{i}$ and $\boldsymbol{\Lambda}_{i}$ are coefficient matrices, $L$ is a lag operator,

\footnotetext{
${ }^{3}$ The model description of this section is largely attributed to Smith and Galesi (2014) and Eickmeier and Ng (2015).
} 
$\boldsymbol{\Phi}_{i}\left(L, p_{i}\right)=\boldsymbol{I}_{k_{i}}-\sum_{l=1}^{p_{i}} \boldsymbol{\Phi}_{i l} L^{l}, \boldsymbol{\Lambda}_{i}\left(L, q_{i}\right)=\sum_{l=1}^{q_{i}} \boldsymbol{\Lambda}_{i l} L^{l}, \boldsymbol{a}_{i, 0}$ is a constant, $t$ is a linear trend, $\boldsymbol{u}_{i, t}$ is a $k_{i} \times 1$ vector of serially uncorrelated disturbances, $\boldsymbol{u}_{i, t} \sim \operatorname{iid}\left(0, \boldsymbol{\Sigma}_{u, i}\right)$.

The foreign variables are constructed as weighted averages of other countries' variables.

$$
\boldsymbol{x}_{i, t}^{*}=\sum_{h=0}^{N} w_{i, h} \boldsymbol{x}_{h, t}
$$

where $w_{i, h}$ is a weight capturing the importance of country $h$ for country $i . \sum_{h=0}^{N} w_{i, h}=1$ and $w_{i, h}=0$ for $h=i$.

Eq. (1) can be written as

$$
\boldsymbol{A}_{i}\left(L, p_{i}, q_{i}\right) \boldsymbol{z}_{i, t}=\boldsymbol{B}_{i, t}+\boldsymbol{u}_{i, t}
$$

where $\boldsymbol{A}_{i}\left(L, p_{i}, q_{i}\right)=\left[\boldsymbol{\Phi}_{i}\left(L, p_{i}\right),-\boldsymbol{\Lambda}_{i}\left(L, q_{i}\right)\right], \boldsymbol{z}_{i, t}=\left(\boldsymbol{x}_{i, t}^{\prime}, \boldsymbol{x}_{i, t}^{* \prime}\right)^{\prime}$ and $\boldsymbol{B}_{i, t}=\boldsymbol{a}_{i, 0}+\boldsymbol{a}_{i, 1} t$.

The following identity can be obtained, using the matrices $\boldsymbol{W}_{i}$ :

$$
\boldsymbol{z}_{i, t}=\boldsymbol{W}_{i} \boldsymbol{x}_{t}
$$

where $\boldsymbol{x}_{t}=\left(\boldsymbol{x}_{0, t}^{\prime}, \boldsymbol{x}_{1, t}^{\prime}, \cdots, \boldsymbol{x}_{N, t}^{\prime}\right)^{\prime}$ is a $k \times 1$ vector that includes all endogenous variables of the system and $\boldsymbol{W}_{i}$ is a $\left(k_{i}+k_{i}^{*}\right) \times k$ matrix and contains the weights based on bilateral trade or capital flows between the countries:

$$
\boldsymbol{W}_{i}=\left(\begin{array}{ccccccc}
0 & 0 & \cdots & \boldsymbol{I}_{k_{i}} & \cdots & 0 & 0 \\
w_{i, 0} \boldsymbol{I}_{k_{i}^{*}} & w_{i, 1} \boldsymbol{I}_{k_{i}^{*}} & \cdots & 0 & \cdots & w_{i, N-1} \boldsymbol{I}_{k_{i}^{*}} & w_{i, N} \boldsymbol{I}_{k_{i}^{*}}
\end{array}\right)
$$

The following equation can be derived from Eqs. (3) and (4):

$$
\boldsymbol{A}_{i}(L, p) \boldsymbol{W}_{i} x_{t}=\boldsymbol{B}_{i, t}+\boldsymbol{u}_{i, t}
$$

where $p=\max \left(p_{0}, p_{1}, \cdots, p_{N}, q_{0}, q_{1}, \cdots, q_{N}\right), \boldsymbol{\Phi}_{i}=0$ if $p-p_{i}>0$ and $\boldsymbol{\Lambda}_{i}=0$ if $p-q_{i}>0$.

These individual country models are stacked to generate the model for all the variables in the global model $\boldsymbol{x}_{i}$ :

$$
\boldsymbol{G}(L, p) \boldsymbol{x}_{t}=\boldsymbol{B}_{t}+\boldsymbol{u}_{t}
$$

where $\boldsymbol{G}(L, p)=\left(\begin{array}{c}\boldsymbol{A}_{0}(L, p) \boldsymbol{W}_{0} \\ \boldsymbol{A}_{1}(L, p) \boldsymbol{W}_{1} \\ \vdots \\ \boldsymbol{A}_{N}(L, p) \boldsymbol{W}_{N}\end{array}\right), \boldsymbol{B}_{t}=\left(\begin{array}{c}\boldsymbol{B}_{0, t} \\ \boldsymbol{B}_{1, t} \\ \vdots \\ \boldsymbol{B}_{N, 0}\end{array}\right), \boldsymbol{u}_{t}=\left(\begin{array}{c}\boldsymbol{u}_{0, \mathrm{t}} \\ \boldsymbol{u}_{1, \mathrm{t}} \\ \vdots \\ \boldsymbol{u}_{N, \mathrm{t}}\end{array}\right)$.

In estimating the model, each variable is tested for the existence of a unit root and Johansen's cointegration test is conducted for the question of whether variables have common stochastic trends. The lag orders of the domestic and foreign variables are 
selected by the Akaike information criterion (AIC). It is estimated that $\boldsymbol{x}_{i, t}^{*}$ are $I(1)$ weakly exogenous for the VARX model parameters.

The identification scheme of this paper is different from some former studies, including that of Galesi and Sgherri (2009), and Vansteenkiste and Hiebert (2011), which use generalized impulse response functions (GIRFs) introduced by Koop et al. (1996) and Pesaran and Shin (1998). Although the results of GIRFs are not influenced by the ordering of variables in the model, the shocks obtained with this approach are a combination of different structural shocks, making it difficult to identify them. Therefore, it would be appropriate to employ orthogonalized impulse response functions (OIRFs) to estimate the effects of monetary policy shocks.

Following Dees et al. (2007), consider the VARX model for the US and let $\boldsymbol{v}_{0, t}$ denote the structural shocks given by

$$
\boldsymbol{v}_{0, t}=\boldsymbol{P}_{0} \boldsymbol{u}_{0, t}
$$

where $\boldsymbol{P}_{0}$ is a $k_{0} \times k_{0}$ matrix of parameters to be identified. The identification conditions of Sims (1980) require $\operatorname{Cov}\left(\boldsymbol{v}_{0, t}\right)=\Sigma_{v 0}$ to be diagonal and $\boldsymbol{P}_{0}$ to be lower triangular. Let $\boldsymbol{Q}_{0}$ denote the upper Cholesky factor of $\operatorname{Cov}\left(\boldsymbol{u}_{0, t}\right)=\Sigma_{u 0}=\boldsymbol{Q}_{0}^{\prime} \boldsymbol{Q}_{0}$ so that $\Sigma_{v 0}=\boldsymbol{P}_{0} \Sigma_{u 0}$ $\boldsymbol{P}_{0}^{\prime}$ with $\boldsymbol{P}_{0}=\left(\boldsymbol{Q}_{0}^{\prime}\right)^{-1}$.

This paper identifies the US monetary policy shocks, using a recursive Cholesky scheme. The ordering of the endogenous variables in the US is as follows: stock prices, oil prices and interest rates.

The GVAR model is bootstrapped in order to obtain the empirical distributions of OIRFs and their error bands. The number of replications is set to 1000 .

\section{Data and model setup}

The data used in this paper cover 23 countries and regions: Australia, Brazil, Canada, China, Hong Kong, India, Indonesia, Japan, South Korea, Malaysia, New Zealand, Norway, the Philippines, Russia, Singapore, South Africa, Sweden, Taiwan, Thailand, Turkey, the UK, the US, and the euro area. The euro area countries are combined into a single economy because a common monetary policy has been applied since 1999 . According to the IMF (2005), they accounted for about $88 \%$ of the world's GDP in 2004.

Weekly frequency data are used in this paper in order to investigate US monetary policy shock effects on global financial markets during relatively shorter terms, in which monthly data cannot capture them. Each country's VARX contains the following variables: stock prices, foreign exchange rates, international oil prices and government bond yields (see Appendix for specific data and sources). This paper uses the logarithm of major stock price indices in each country, the logarithm of the bilateral exchange rate against the US dollar, the logarithm of the price on crude oil WTI (NYMEX), and

\footnotetext{
${ }^{4}$ Even if the ordering of the variables was changed, almost the same results could be obtained as in the benchmark analysis.
} 
Krippner's shadow short rates for the US, the UK, the euro area and Japan, and 1-year (90-day or 2-year if not available) government bond rates for the other countries.

This paper uses bilateral portfolio investment liabilities as the weights of the GVAR scheme because inter-country relations in the short run could be relatively largely affected by financial movements rather than international trade. Specifically, the data are obtained from "derived portfolio investment liabilities (all economies) by economy of nonresident holder" in the Coordinated Portfolio Investment Survey (CPIS), the $\mathrm{IMF}^{5}$

VARX models for all countries except the US contain stock prices, interest rates and foreign exchange rates as endogenous variables, and foreign stock prices, interest rates, exchange rates and the oil price as exogenous variables. The US model includes stock prices, interest rates and the oil price as endogenous variables, and bilateral exchange rates against the US dollar, other countries' stock price indices and interest rates as exogenous variables. ${ }^{6}$

The period analyzed in this paper is from January 9, 2004 through December 29, 2017 . $^{7}$ This paper divides the period into five subperiods. ${ }^{8}$ Specifically, Subperiod 1A is from January 9, 2004 through January 12, 2007, in which conventional monetary tightening policy was applied. Subperiod 1B is from January 19, 2007 through July 11, 2008 , in which conventional monetary easing policy was conducted. Subperiod 2A is from December 19, 2008 through December 20, 2013, in which unconventional monetary easing policy was implemented. Subperiod 2B is from December 27, 2013 through December 25, 2015, in which unconventional monetary tightening policy was employed, but the US shadow federal funds rate was negative. Subperiod $2 \mathrm{C}$ is from July 10, 2015 through December 29, 2017, in which unconventional monetary tightening policy was applied but a policy rate hike began, and the amount of the Federal Reserve's total assets remained at around 4.4 million dollars. ${ }^{9}$

\section{Empirical results}

This section examines impulse response results for each subperiod to determine differences between conventional and unconventional policies, and between tightening and easing policies. In the figures below, median impulse responses are indicated in solid lines with $90 \%$ confidence bands shown in dotted lines.

\footnotetext{
${ }^{5}$ Using the assets data reported by CPIS participating economies, the IMF derives liabilities data for all economies (CPIS reporters as well as non-reporters); these data are termed "derived liabilities."

${ }^{6}$ Dees et al. (2007) and Eickmeier and $\mathrm{Ng}$ (2015) also include the oil price as an endogenous variable in the US model. The weak exogeneity assumptions are not rejected at the $5 \%$ significance level with the exception of 14 out of 141 cases. This does not seem to be too serious a violation because almost the same results could be obtained when variables, in which exogeneity assumptions are rejected at the $5 \%$ significance level, are excluded in the estimations.

${ }^{7}$ In this paper the date denotes a week ending on that day.

${ }^{8}$ Ono (2018) also divides the period into conventional tightening, conventional easing, unconventional easing and unconventional tightening subperiods.

9 The data are available at https://www.federalreserve.gov/monetarypolicy/ bst_recenttrends.htm. In order to guarantee a sufficient number of data, the beginning of Subperiod 2C is set to July 10, 2015, the first week of the second half of 2015 .
} 


\subsection{Subperiod 1A (conventional monetary tightening policy)}

Figure 1 shows the responses of each country's stock prices to a one percentage point positive US federal funds rate shock. The results suggest that the stock prices of all countries showed significant negative responses in around the fourth period, but the effects were temporary and later the responses became statistically insignificant. On the other hand, foreign exchange rates for 19 countries and areas showed positive responses (depreciation) with statistical significance and interest rates for 18 countries and areas responded positively with statistical significance (figures of the results are not presented to economize on space).
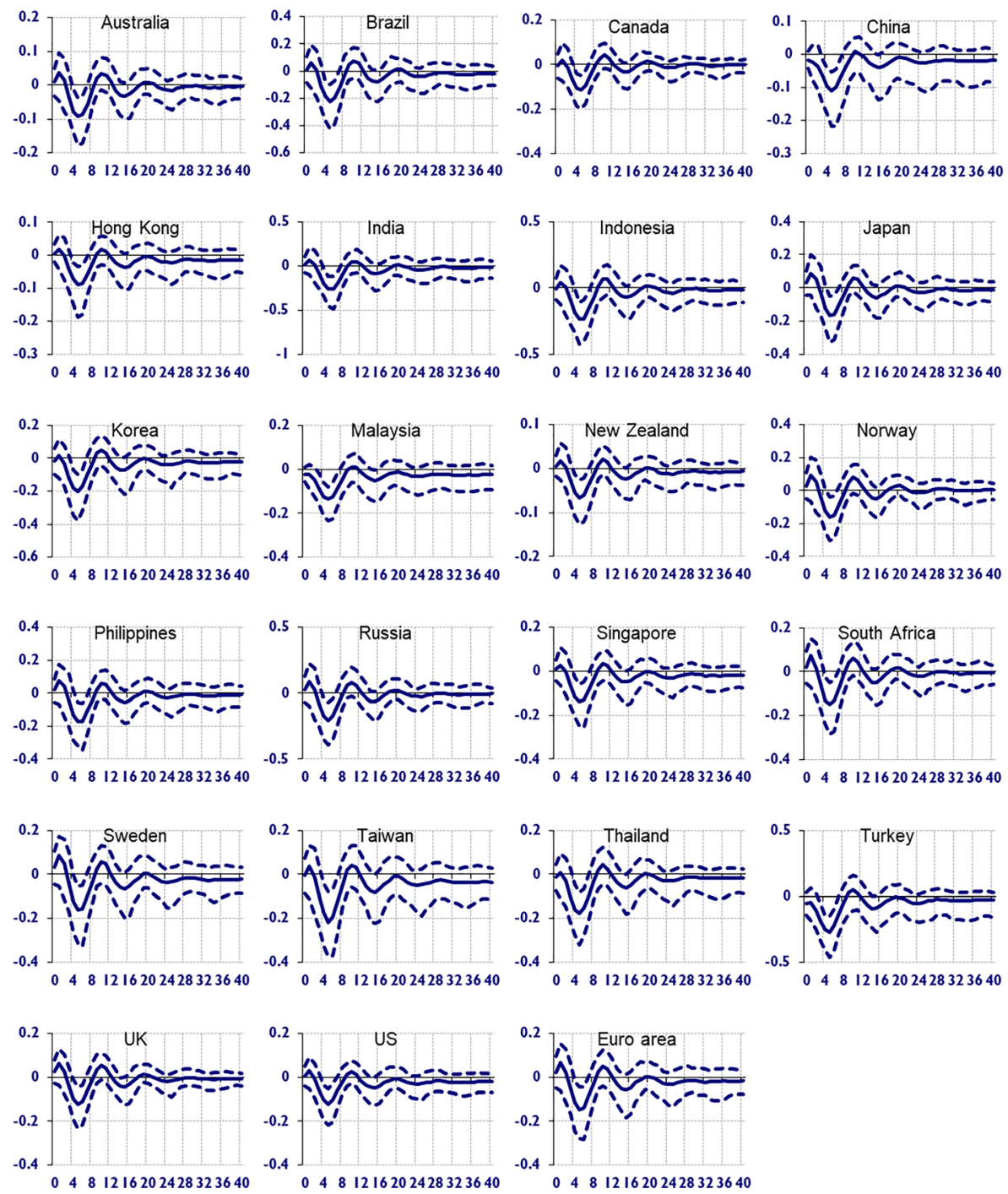

Fig. 1 Impulse responses of stock prices to a one percentage point positive shock of the US federal funds rate for Subperiod 1A 
The results indicate that conventional monetary tightening policy acts like pulling on a string in an economic boom and decreases stock prices not only in the US, but also in countries around the world.

\subsection{Subperiod 1B (conventional monetary easing policy)}

Figure 2 shows the responses of each country's stock prices to a one percentage point negative US federal funds rate shock. The results suggest that the stock prices of 14 countries and areas showed significant negative responses in around the second period although an expansionary monetary policy shock was given (later all the responses became statistically insignificant).
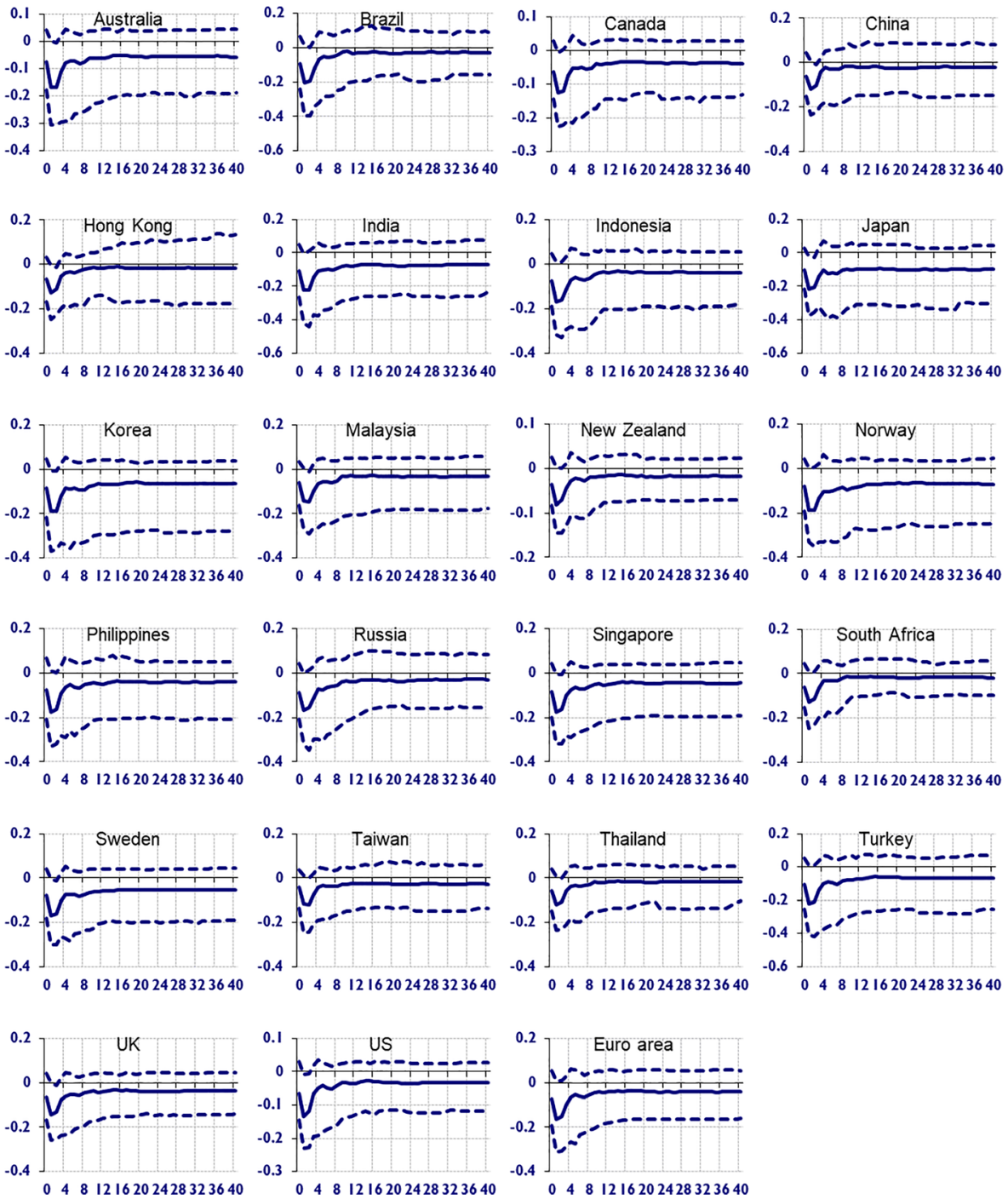

Fig. 2 Impulse responses of stock prices to a one percentage point negative shock of the US federal funds rate for Subperiod 1B 
The responses of foreign exchange rates were not significant for most countries whereas interest rates of 13 countries responded negatively with statistical significance only for earlier periods (figures of these results are not presented to economize on space).

The above-mentioned results suggest that although conventional monetary easing policy lowered interest rates temporarily, it decreased stock prices in many countries. Therefore, conventional monetary easing policy acts like pushing on a string in a recession, producing little positive effect on the stock prices of the US as well as countries around the world contrary to conventional monetary tightening policy.

\subsection{Subperiod 2A (unconventional monetary easing policy)}

According to Fig. 3, all countries' stock prices responded negatively with statistical significance. The unconventional US monetary easing was supposed to alleviate the impacts of the global financial turmoil. The measures, however, could provoke a conjecture that the crisis was so serious that the Fed was forced to take an unprecedented measure, giving a downward pressure on stock markets. The responses of unconventional monetary easing are persistent while those of conventional monetary easing are temporary. Whereas Hajek and Horvath (2018) claim that the effects of unconventional monetary policy measures of the European Central Bank (ECB) on consumer prices are weaker than those of conventional measures, this paper revealed that the effects of the Fed's unconventional monetary policy measures on stock prices were weaker than conventional measures.

Figure 4 shows the responses of foreign exchange rates. The unconventional monetary easing shock depreciates exchange rates against the US dollar in 19 countries with statistical significance while it appreciates the Japanese yen and the Chinese RMB.

The reason that the Japanese yen responds negatively (appreciates) could be related to yen-carry trade. It is said that large amounts of funds denominated in the Japanese yen were raised at low interest rates and were invested in assets that provide higher rates of return. As indicated in Mogford and Pain (2006), the Commitments of Traders Report (COTR) of the Commodity Futures Trading Commission (CFTC) provide a breakdown of positions in futures for markets traded on a number of exchanges, including the International Money Market (IMM), a division of the Chicago Mercantile Exchange (CME). These data could be a bellwether for yen-carry trade trends. While the number of net short speculative futures for the yen against the US dollar was nearly 200,000 in mid-2007, net speculative futures positions tended to be long after 2008. This suggests that the development of the crisis could induce financial institutions to unwind their transactions, that is, sell assets and repay yen-denominated funds. These circumstances could cause the yen to appreciate against the US dollar during the financial crisis.

As for the Chinese RMB, in light of the turbulent international financial markets due to the subprime crisis, China effectively fixed the exchange rate to the US dollar in July 2008, and the managed float resumed at around July 2010 (Ito, 2017). After that, the RMB tended to appreciate against the US dollar. The RMB's negative responses could reflect these circumstances.

The findings of this paper regarding exchange rate responses are almost consistent with those of Eickmeier and $\mathrm{Ng}$ (2015), who claim that exchange rate responses to a negative credit supply shock show a flight to quality to the US dollar, using data from 1983 through 2009. This paper's findings, however, are different from those of 

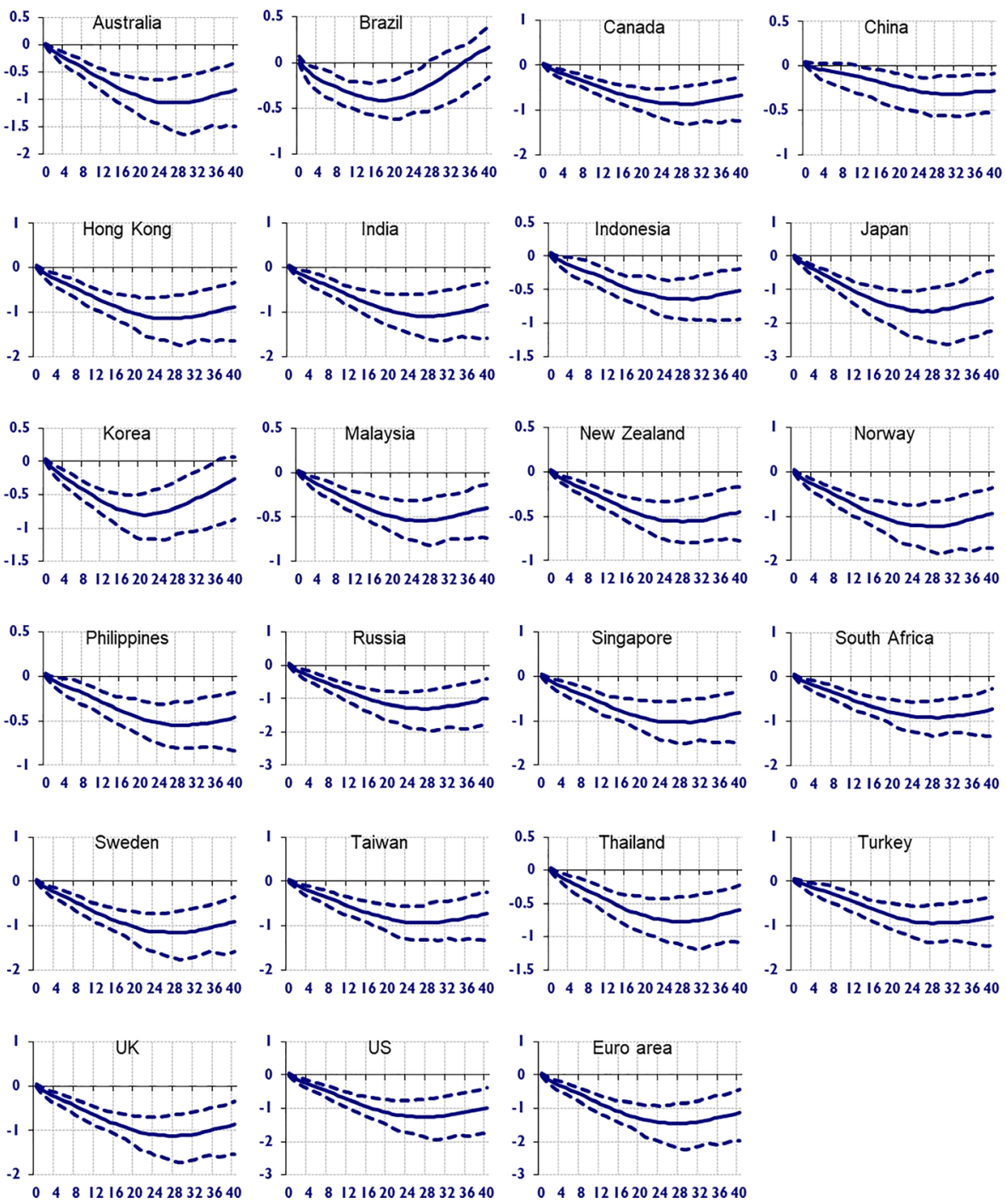

Fig. 3 Impulse responses of stock prices to a one percentage point negative shock of the US federal funds rate for Subperiod 2A

Eickmeier and $\mathrm{Ng}$ (2015) in the sense that an unwinding of Japanese yen-carry trade or yen appreciation was detected possibly due to using the weekly series. Moreover, this paper revealed a difference between unconventional and conventional monetary easing by introducing subperiods as in the latter a flight to quality to the US dollar was not detected in the long run.

Figure 5 shows the responses of interest rates. The results suggest that interest rates in 20 countries responded negatively with statistical significance, including countries, in which responses of interest rates became statistically insignificant in later periods. This implies that sufficient liquidity could be supplied around the world. On the other hand, Russia demonstrated significant positive responses to a US interest rate shock. 

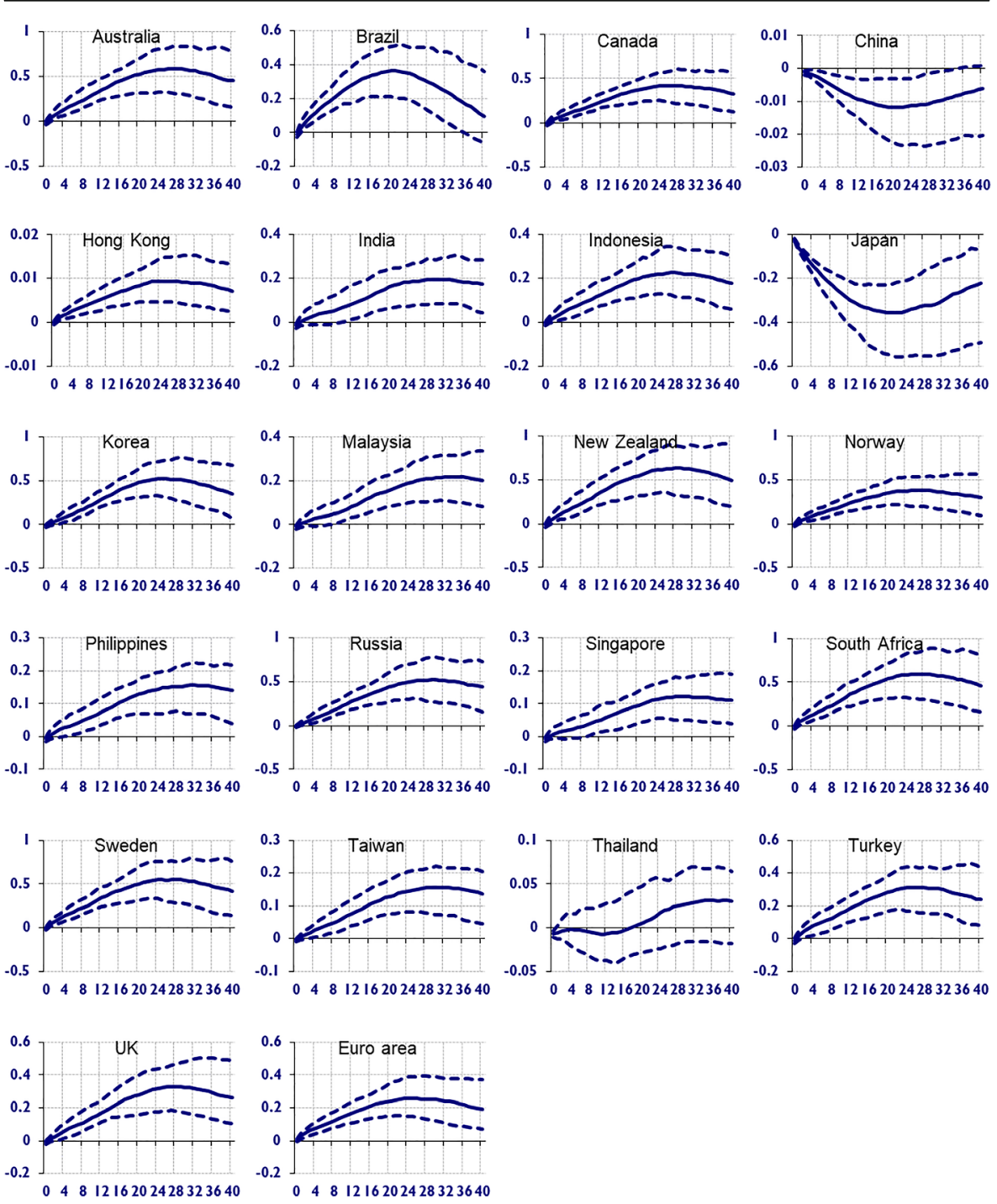

Fig. 4 Impulse responses of foreign exchange rates to a one percentage point negative shock of the US federal funds rate for Subperiod 2A

According to the OECD (2011), at the end of 2008, the Central Bank of Russia (CBR) engaged in a tightening cycle in an attempt to counteract depreciation and inflationary pressures. This was in sharp contrast to the majority of the OECD central banks, which drastically reduced their policy rates at that time (OECD 2011). This stance of the CBR could be reflected in the results of impulse responses.

\subsection{Subperiod 2B (unconventional monetary tightening policy)}

Figure 6 shows the responses of stock prices to a one percentage point positive US shadow federal funds rate shock. The results indicate that the stock price responses of 

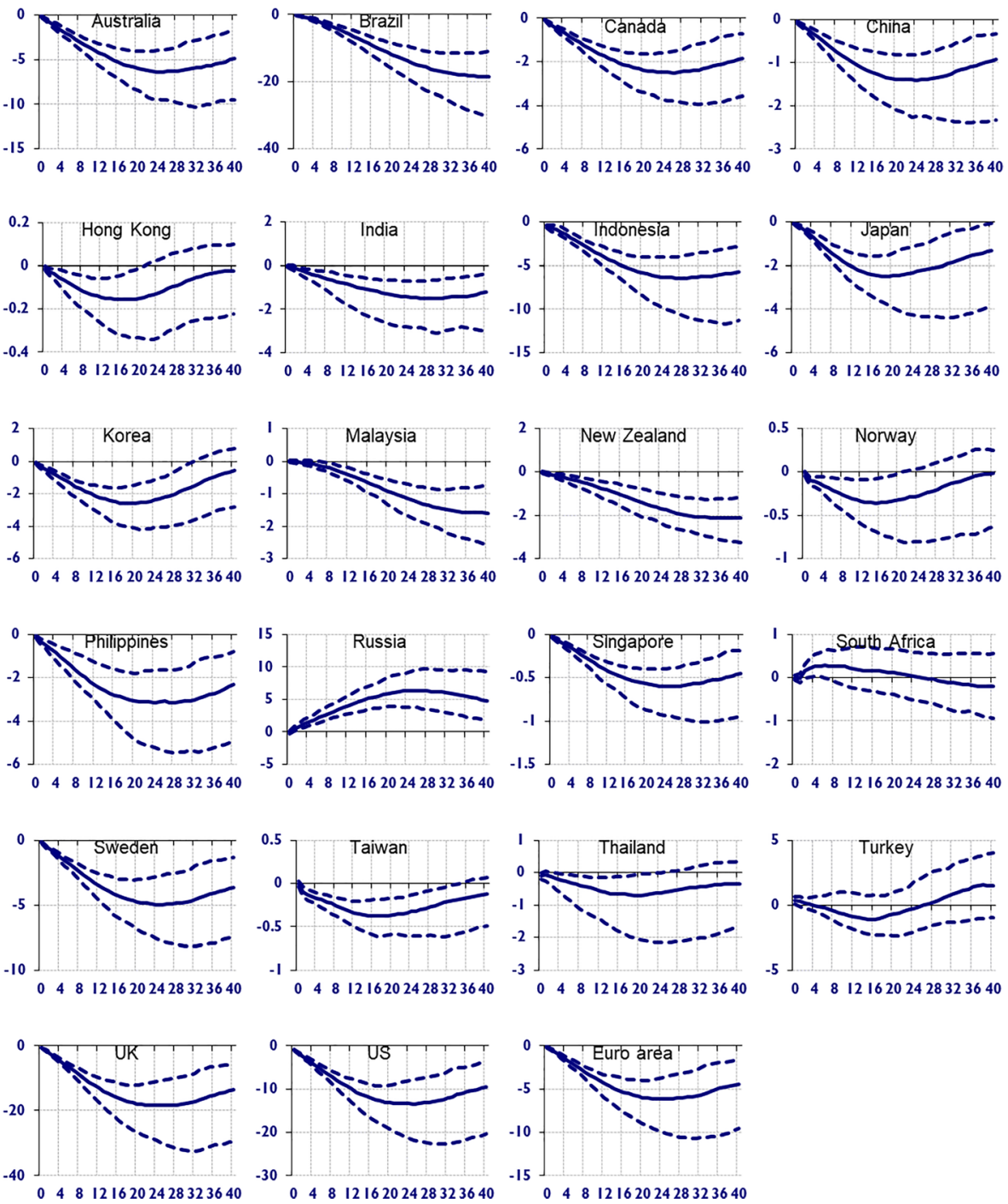

Fig. 5 Impulse responses of interest rates to a one percentage point negative shock of the US federal funds rate for Subperiod 2A

all countries except China and Japan are negative with statistical significance. Although the intention of the Fed would be not to affect stock markets by its tightening policy stance, its policy management had negative effects on the stock markets, judging from the results of impulse responses. ${ }^{10}$

On the other hand, the exchange rates of 19 countries responded positively (depreciated) with statistical significance (including temporarily significant cases), reflecting a rise in US shadow interest rates.

\footnotetext{
${ }^{10}$ Although Ahmed et al. (2017) claim that emerging market economies with relatively better economic fundamentals suffered less deterioration in financial markets during the 2013 taper-tantrum episode, this study demonstrated a persistent decrease in stock prices for almost all countries in the analysis of Subperiod 2B.
} 
As for interest rates, the responses in 12 countries were significantly positive (including temporarily significant cases) whereas the interest rate of Japan responded negatively with statistical significance to a positive US federal funds rate shock. The Bank of Japan (BOJ) introduced quantitative and qualitative monetary easing (QQE) in April 2013, expanded it in October 2014, and introduced supplementary measures in December 2015. ${ }^{11}$ The stance of the BOJ could reflect the above-mentioned negative responses of interest rates in Japan.

Moreover, oil prices showed persistent negative responses with statistical significance. This suggests that liquidity could decrease and there was growing concern that economic activities around the world would slow down.

\subsection{Subperiod $2 \mathrm{C}$ (unconventional monetary tightening policy, the phase of the exit from a rate of zero or near-zero)}

Figure 7 shows the responses of stock prices to a one percentage point positive US federal funds rate shock. The results indicate that stock prices in 17 countries responded negatively with statistical significance (including temporarily significant cases). The US monetary tightening policy shock at the actual (not shadow) interest rate hike phase could effectively affect the stock prices of the US as well as around the world as is the case with a conventional US monetary tightening shock. However, the former effects are persistent but those of the latter are temporary.

Foreign exchange rates of 19 countries responded positively (depreciated) with statistical significance, which reflects the interest rate hike in the US and the increasing buying pressure for the US dollar. Although the results are the same as the case in a conventional US monetary tightening shock, the former effects are persistent and those of the latter are temporary. This could be interpreted as follows. Because a conventional monetary tightening policy measure is taken under the backdrop of favorable economic circumstances, a US interest rate hike does not induce persistent unwinding of transactions. On the other hand, in the case of an unconventional monetary tightening policy, liquidity provided throughout the world could be unwound, prompting economic entities to purchase the US dollar.

Next, interest rates in 14 countries responded positively with statistical significance in the earlier periods, but they turned insignificant in 8 out of those 14 countries. Only Japanese interest rates showed persistent negative responses with statistical significance, reflecting the continuing QQE policy in Japan.

Moreover, the responses of oil prices were insignificant although their responses were persistently significant in Subperiod 2B.

\section{GVAR-based counterfactual analysis}

This section investigates the transmission of a US monetary policy shock to stock prices via exchange rates by counterfactual analysis. In estimated parameter matrices

\footnotetext{
${ }^{11}$ For details, see the BOJ's website https://www.boj.or.jp/en/mopo/outline/qqe.htm/. Bauer \& Neely (2014) claim that portfolio balance effects were small for Japanese yields and signaling effects basically nonexistent.
} 

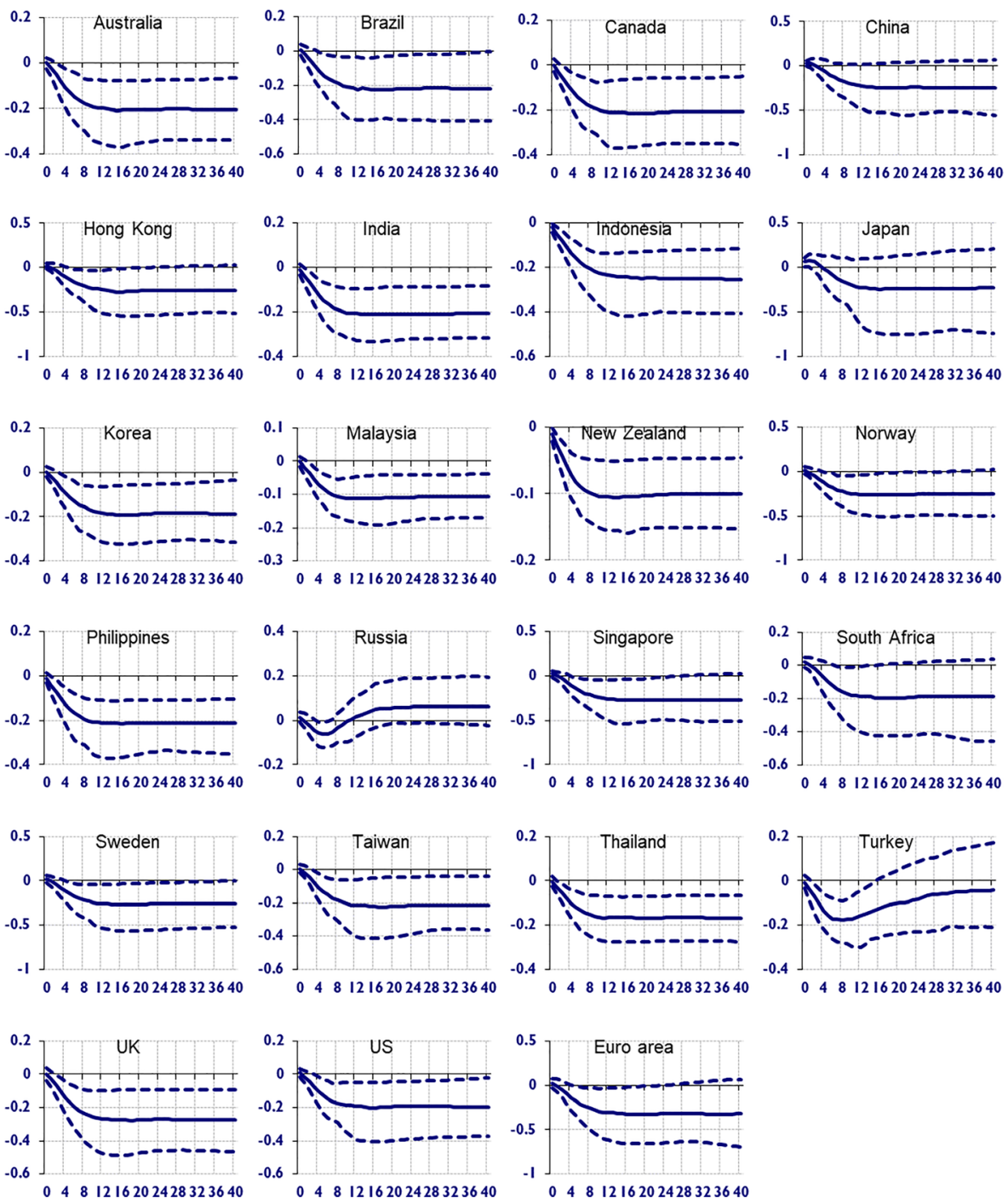

Fig. 6 Impulse responses of stock prices to a one percentage point positive shock of the US federal funds rate for Subperiod 2B

$\hat{\mathbf{G}}_{j}, j=0,1, \cdots, p$, the effects of all variables on exchange rates are counterfactually set to zero. Moreover, in the estimated covariance matrix $\hat{\Sigma}_{u}$, all covariances between the exchange rate variables and all other variables are counterfactually set to zero. Then, impulse responses are assessed on the basis of counterfactual coefficients and covariance matrices.

In Subperiod 1A, counterfactual impulse responses are generally larger in a negative direction than original responses (Fig. 8). This suggests that the effects of a positive US federal funds rate shock on stock prices are attenuated by the transmission via exchange rates. It should be noted, however, that the attenuation of the decrease in stock prices is at most about $0.1 \%$. 

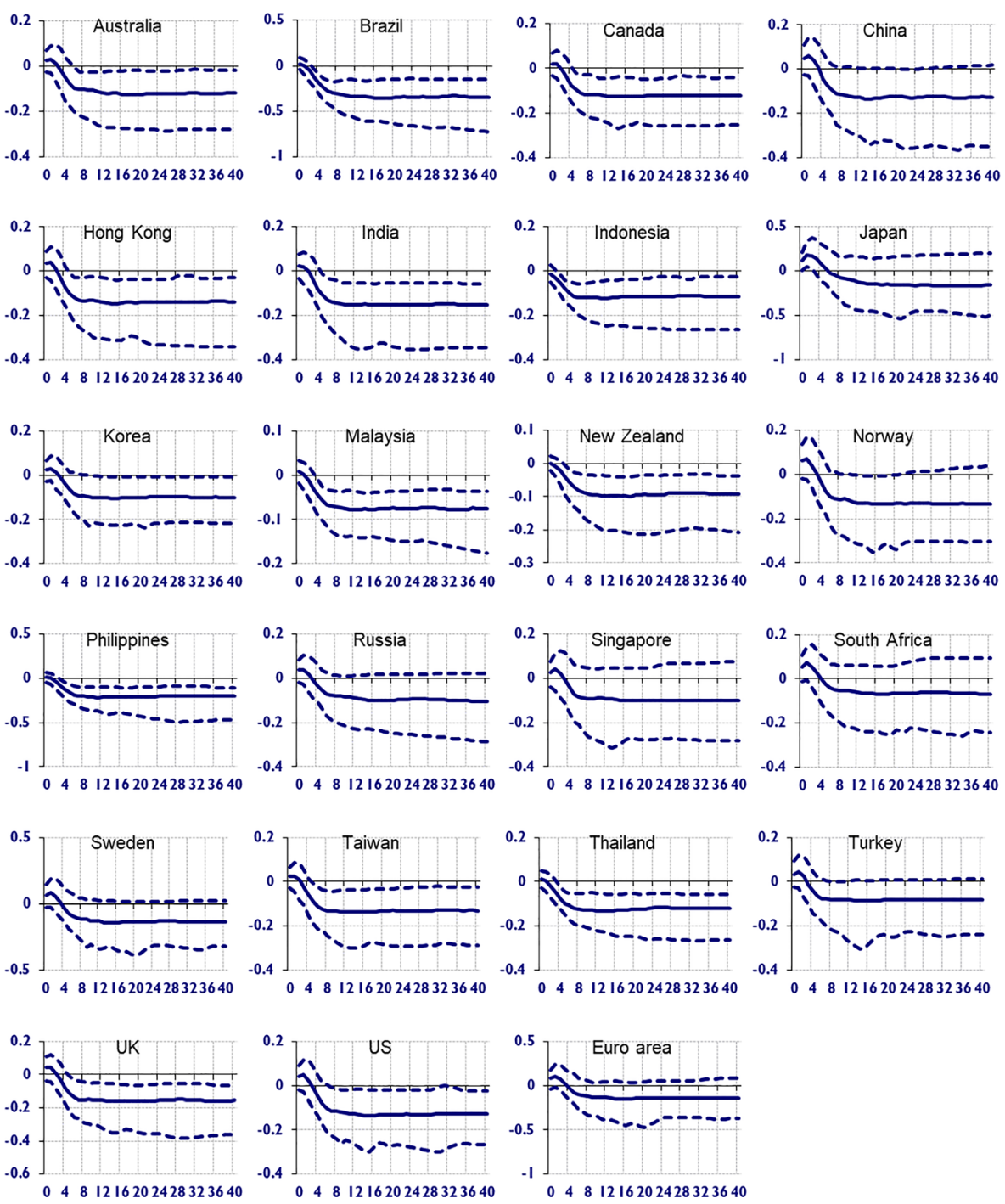

Fig. 7 Impulse responses of stock prices to a one percentage point positive shock of the US federal funds rate for Subperiod $2 \mathrm{C}$

As for Subperiod 1B, transmission effects via exchange rates are relatively larger in Brazil, Russia, the Philippines and South Africa, showing a downward pressure on stock prices although the responses of exchange rates to a US interest rate shock are not significant for these countries (Fig. 9). On the other hand, transmission effects in developed countries, such as Japan and the euro area are also larger. This can be explained by the statistically significant negative responses (appreciation) of the yen and the euro to a US monetary policy shock. The transmission could be one of the causes of the stock price decrease in all countries except Hong Kong.

The counterfactual impulse responses in Subperiod 2A show that the transmission effects on the stock prices of Japan and Turkey are relatively larger (Fig. 10). 

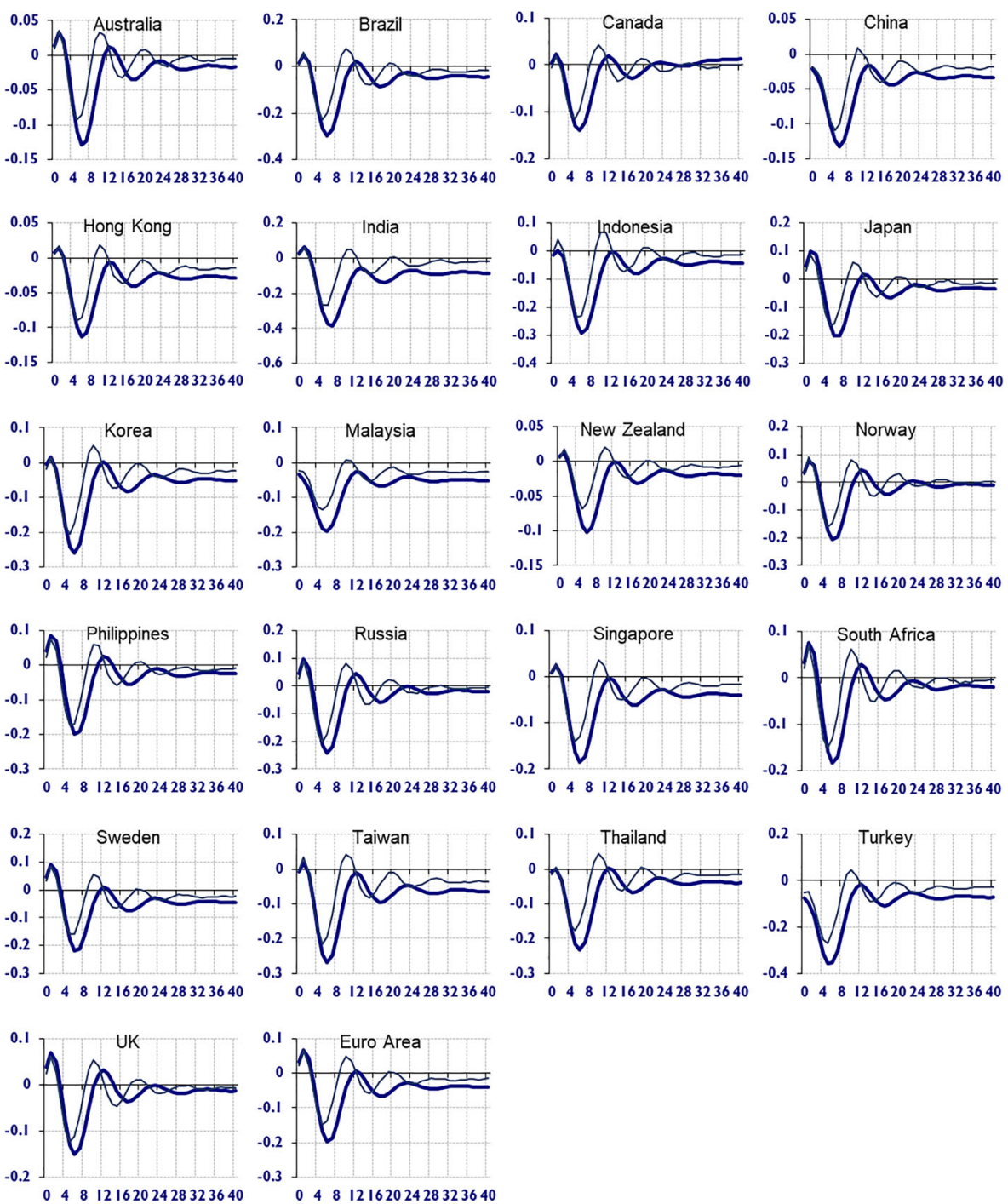

Fig. 8 Original (thin lines) and counterfactual (thick lines) impulse responses of stock prices for Subperiod 1A

Specifically, a US interest rate shock transmitted via the exchange rate channel to these countries to decrease their stock prices by up to $0.89 \%$ for Japan and $0.96 \%$ for Turkey. The drop in the Japanese stock prices can be explained by the appreciation of the yen. On the other hand, the stock prices of Turkey decreased under the depreciation of the lira. The reason for this could be its high rate of short-term debts relative to reserve assets. The rate is $71.3 \%$ for Turkey in $2008 .^{12}$

Counterfactual impulse responses for Subperiod 2B suggest that the transmission effects decrease stock prices in all countries analyzed in this paper (Fig. 11). This

\footnotetext{
${ }^{12}$ The figures of Turkey were derived from the following website of the World Bank: https://data.worldbank. org/indicator/DT.DOD.DSTC.IR.ZS.
} 

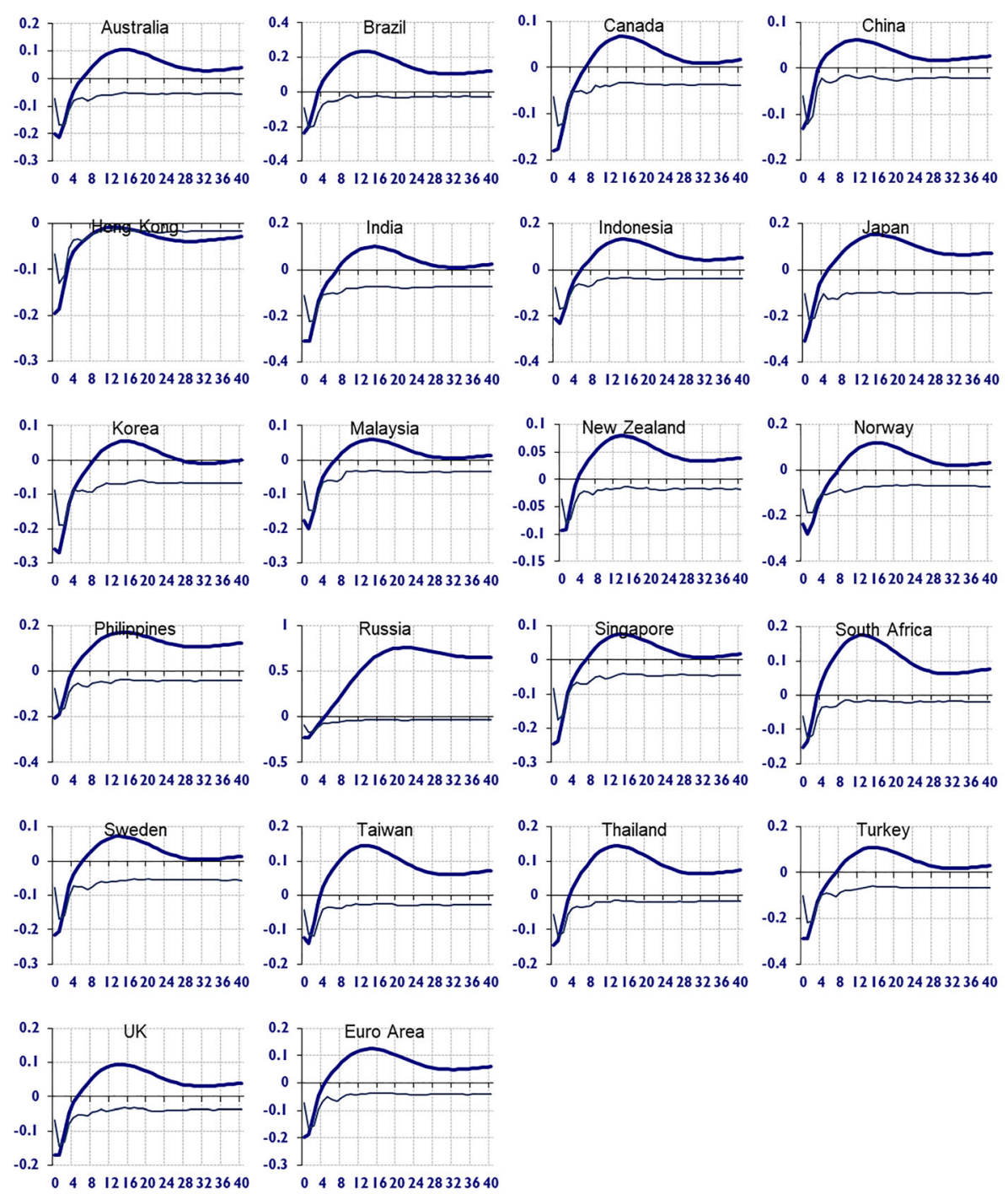

Fig. 9 Original (thin lines) and counterfactual (thick lines) impulse responses of stock prices for Subperiod 1B

implies that the Fed's potential intention to raise interest rates induced the outflow of funds especially from developing countries, which causes the depreciation of exchange rates against US dollar and the decrease in stock prices. Countries with a larger transmission effect via the exchange rate channel on stock prices are Turkey (the decrease in stock prices by the transmission effect by up to $0.40 \%)$, Brazil $(0.18 \%)$, China $(0.12 \%)$, Russia $(0.11 \%)$ and Indonesia $(0.10 \%)$.

Counterfactual analysis for Subperiod $2 \mathrm{C}$ suggests that the decrease in stock prices are attenuated by the transmission for Brazil by $0.454 \%$, Russia by $0.057 \%$, Turkey by $0.050 \%$, Indonesia by $0.045 \%$, Taiwan by $0.044 \%$, and South Africa by 0.040 (Fig. 12). Because exchange rates for these countries showed persistent positive responses to a US monetary policy shock with statistical significance, the depreciation 

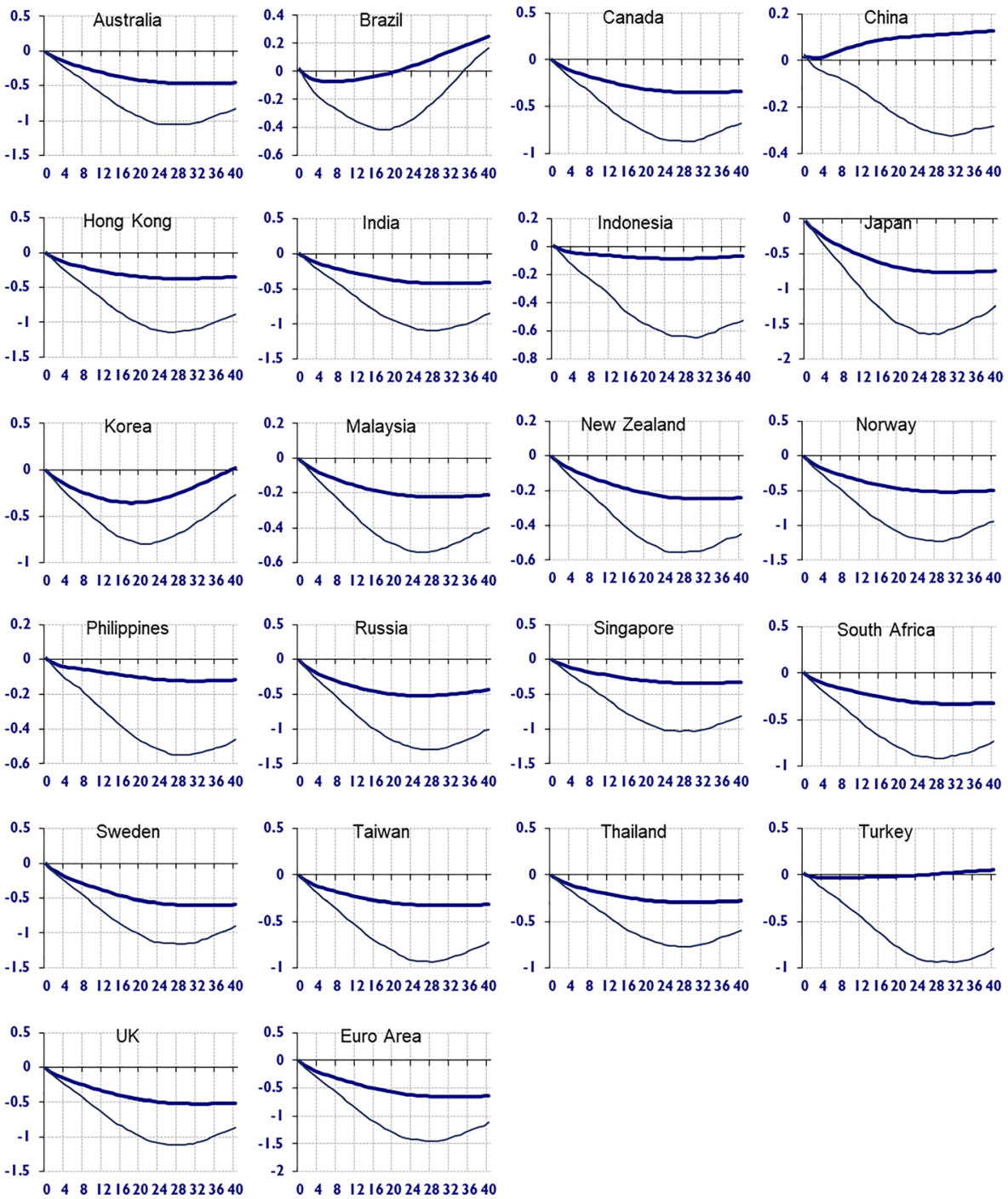

Fig. 10 Original (thin lines) and counterfactual (thick lines) impulse responses of stock prices for Subperiod $2 \mathrm{~A}$

of these countries' currencies could attenuate the shock. On the other hand, the stock prices of Japan and the euro area are pushed down by the transmission by $0.10 \%$ and $0.07 \%$, respectively although the responses of their exchange rates are statistically insignificant in the long run.

To recapitulate the above-mentioned arguments, the transmission of a US monetary policy shock to stock prices via exchange rates tends to push down the stock prices of many countries both in the conventional and unconventional monetary easing phases. On the other hand, the transmission tends to attenuate the decrease in stock prices for many countries both in the conventional tightening phase and the unconventional tightening phase (the phase of the exit from a rate of zero). However, in the 

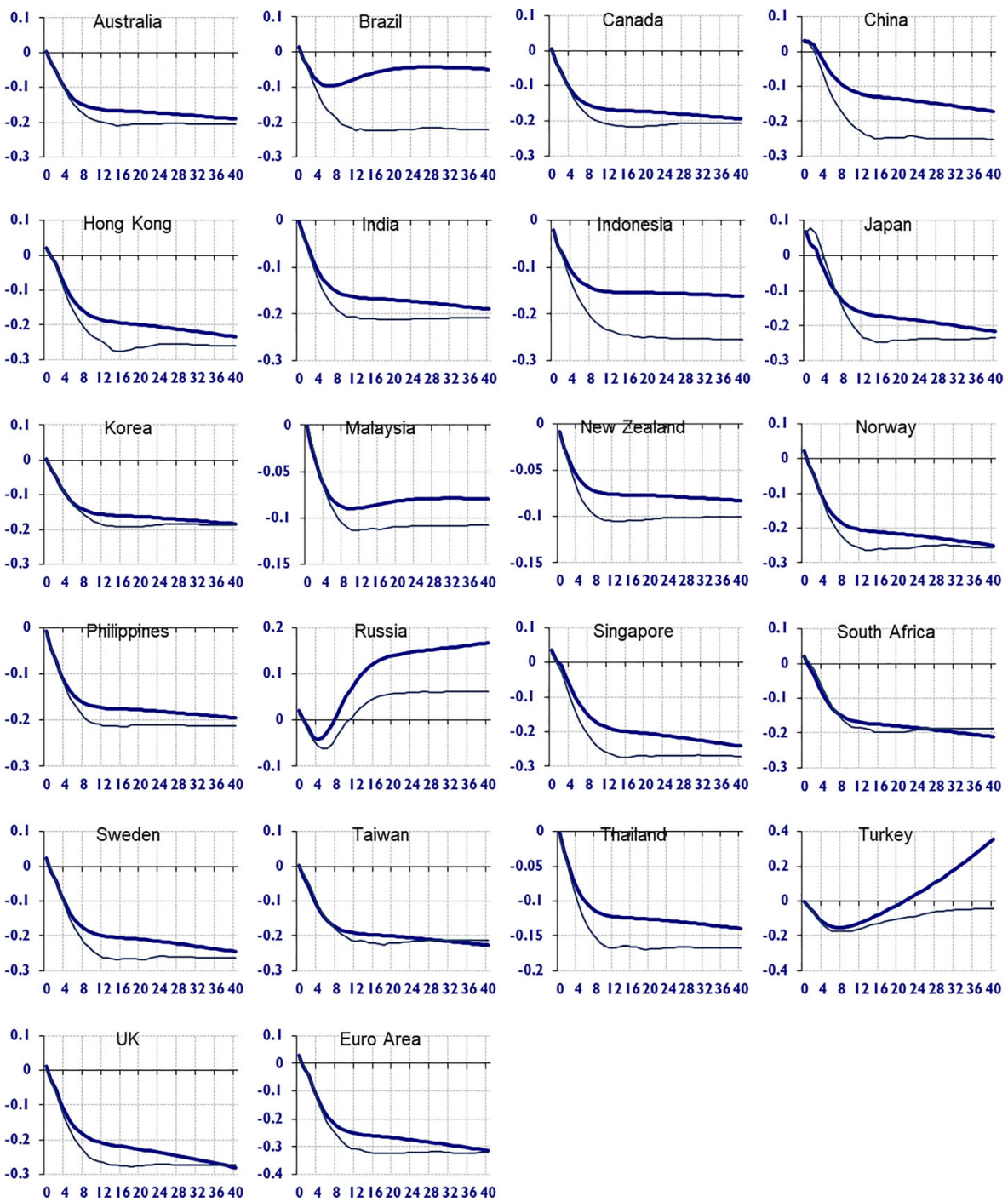

Fig. 11 Original (thin lines) and counterfactual (thick lines) impulse responses of stock prices for Subperiod $2 \mathrm{~B}$

unconventional monetary tightening phase (shadow federal funds rate is negative) the transmission tended to intensify the decrease in stock prices as in the monetary easing phases.

\section{Conclusions}

This paper investigates the impacts of conventional and unconventional US monetary policies on global financial markets with weekly data of 23 countries and areas, employing the GVAR models. The period analyzed in the paper is divided into five 

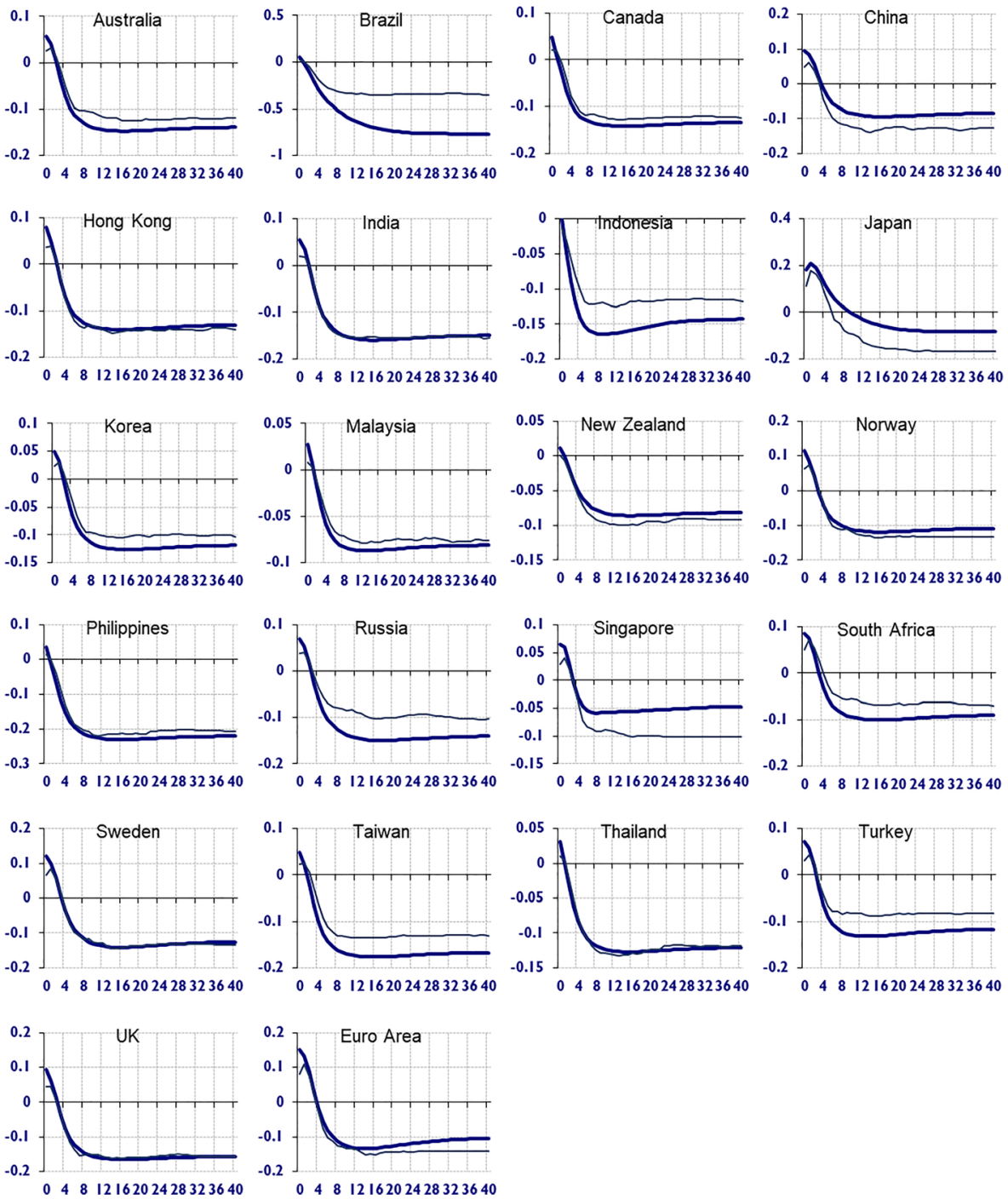

Fig. 12 Original (thin lines) and counterfactual (thick lines) impulse responses of stock prices for Subperiod $2 \mathrm{C}$

subperiods: conventional tightening (1A), conventional easing (1B), unconventional easing (2A), unconventional tightening (shadow federal funds rate is negative) (2B), and unconventional tightening (a policy rate is no longer at zero or near-zero) (2C) phases (see Table 1 for the summary of impulse responses).

The results of impulse response analysis are as follows. The stock prices of many countries in Subperiods 1A and 1B showed temporary negative responses with statistical significance although an expansionary monetary policy shock was given in Subperiod 1B. This suggests that conventional monetary easing policy produces little positive effects on the economies of the US as well as countries around the world in contrast to conventional monetary tightening policy. 
Table 1 Summary of impulse responses to a US monetary policy shock

\begin{tabular}{llll}
\hline & Stock prices & Exchange rates & Interest rates \\
\hline Subperiod 1A & $\begin{array}{l}\text { Negative } \\
\text { temporary }\end{array}$ & $\begin{array}{l}\text { Positive } \\
\text { temporary }\end{array}$ & $\begin{array}{l}\text { Positive } \\
\text { temporary }\end{array}$ \\
Subperiod 1B & Negative & & Negative \\
& temporary & temporary \\
Subperiod 2A & Negative & Positive \\
persistent & persistent & Negative \\
Subperiod 2B & persitive & Positive & persistent \\
& Negative & persistent & Positive \\
Subperiod 2C & persistent & Positive & temporary \\
& persistent & Positive \\
& temporary
\end{tabular}

(Note) If ten or more countries/areas show statistical significance, their responses are indicated in the table

In Subperiod 2A all countries' stock prices responded negatively with statistical significance. The unconventional monetary easing had little positive effect on stock prices as in conventional easing. However, the responses of the former are persistent while those of the latter are temporary. Moreover, an unconventional monetary easing shock depreciates exchange rates against the US dollar, showing a flight to quality to the US dollar, whereas that of conventional monetary easing did not induce a flight to quality in the long run. This paper also detected an unwinding of Japanese yen-carry trade or yen appreciation. The responses of interest rates were significantly negative in 18 countries, which means liquidity was provided throughout the world.

In Subperiods $2 \mathrm{~B}$ and $2 \mathrm{C}$ the stock price responses of many countries are persistent negative with statistical significance as is the case with a conventional US monetary tightening shock. The responses of stock prices, exchange rate, interest rates suggest that there was growing concern that economic activities around the world would slow down.

Furthermore, counterfactual analysis shows that the transmission of a US monetary policy shock to stock prices via exchange rates tends to attenuate the decrease in stock prices both in the conventional and unconventional tightening (the exit from a zero rate) phases. On the other hand, the transmission tends to push down stock prices in the conventional and unconventional monetary easing phases as well as in the unconventional tightening (the shadow federal funds rate is negative) phase (see Table 2).

Future studies should address the development of the balance sheet normalization of the Fed and other central banks and examine its effects on worldwide financial markets.

Table 2 Summary of transmission of a US monetary policy shock to stock prices via exchange rates

\begin{tabular}{ll}
\hline Subperiod 1A & Attenuating the decrease in stock prices \\
Subperiod 1B & Pushing down stock prices \\
Subperiod 2A & Pushing down stock prices \\
Subperiod 2B & Pushing down stock prices \\
Subperiod 2C & Attenuating the decrease in stock prices especially for emerging countries
\end{tabular}


Acknowledgements This work was supported by JSPS KAKENHI Grant Number 17 K03701.

\section{Appendix. Data for stock prices and interest rates}

Country
Australia
Brazil
Canada
China
Hong Kong
India
Indonesia
Japan
South Korea
Malaysia
New Zealand
Norway
Philippines
Russia
Singapore
South Africa
Sweden
Taiwan
Thailand
Turkey
UK
US

Euro area

\section{Data for stock prices and interest rates}

All Ordinaries Index, 1-year government bond rates

BOVESPA Index, 1-year government bond rates

$\mathrm{S} \& \mathrm{P} / \mathrm{TSX}$ Composite index, 1-year government bond rates

Shanghai Composite Index, 1-year government bond rates

Hang Seng Index, 1-year government bond rates

S\&P BSE SENSEX, 1-year government bond rates

Jakarta Composite Index, 1-year government bond rates

Nikkei 225 Index, Krippner's shadow interest rates for the yen

KSE Composite Index, 1-year government bond rates

FTSE Bursa Malaysia KLCI, 1-year government bond rates

S\&P/NZX 50 index, 90-day bank bill yields

Oslo All Share Index, 1-year government bond rates

Philippine Stock Exchange Index, 1-year government bond rates

MICEX (MOEX), 1-year government bond rates

FTSE Singapore Index, 1-year government bond rates

FTSE/JSE 40, 90-day bank bill yields

OMX Stockholm 30, 2-year government bond rates

TSEC weighted index, 2-year government bond rates

SET Index, 1-year government bond rates

Borsa Istanbul 100 Index, 1-year government bond rates

FTSE 100, Krippner's shadow interest rates for the pound

S\&P 500, Krippner's shadow interest rates for the US dollar

Euro Stoxx 50, Krippner's shadow interest rates for the euro

(Sources) Thomson Reuters, each country’s central banks and stock exchanges

Open Access This article is licensed under a Creative Commons Attribution 4.0 International License, which permits use, sharing, adaptation, distribution and reproduction in any medium or format, as long as you give appropriate credit to the original author(s) and the source, provide a link to the Creative Commons licence, and indicate if changes were made. The images or other third party material in this article are included in the article's Creative Commons licence, unless indicated otherwise in a credit line to the material. If material is not included in the article's Creative Commons licence and your intended use is not permitted by statutory regulation or exceeds the permitted use, you will need to obtain permission directly from the copyright holder.To view a copy of this licence, visit http://creativecommons.org/licenses/by/4.0/.

\section{References}

Ahmed S, Zlate A (2014) Capital flows to emerging market economies: a brave new world? J Int Money Financ 48:221-248. https://doi.org/10.1016/j.jimonfin.2014.05.015 
Ahmed S, Coulibaly B, Zlate A (2017) International financial spillovers to emerging market economies: how important are economic fundamentals? J Int Money Financ 76:133-152. https://doi.org/10.1016/j. jimonfin.2017.05.001

Anaya P, Hachula M, Offermanns CJ (2017) Spillovers of US unconventional monetary policy to emerging markets: the role of capital flows. J Int Money Financ 73:275-295. https://doi.org/10.1016/j. jimonfin.2017.02.008

Barroso JBR, da Silva LAP, Sales AS (2016) Quantitative easing and related capital flows into Brazil: measuring its effects and transmission channels through a rigorous counterfactual evaluation. $\mathrm{J}$ Int Money Financ 67:102-122. https://doi.org/10.1016/j.jimonfin.2015.06.013

Bauer MD, Neely CJ (2014) International channels of the Fed's unconventional monetary policy. J Int Money Financ 44:24-46. https://doi.org/10.1016/j.jimonfin.2013.12.007

Bowman D, Londono JM, Sapriza H (2015) US unconventional monetary policy and transmission to emerging market economies. J Int Money Financ 55:27-59. https://doi.org/10.1016/j. jimonfin.2015.02.016

Chen Q, Filardo A, He D, Zhu F (2016) Financial crisis, US unconventional monetary policy and international spillovers. J Int Money Financ 67:62-81. https://doi.org/10.1016/j.jimonfin.2015.06.011

Chudik A, Fratzscher M (2011) Identifying the global transmission of the 2007-2009 financial crisis in a GVAR model. Eur Econ Rev 55:325-339. https://doi.org/10.1016/j.euroecorev.2010.12.003

Dees S, Mauro F, Pesaran M, Smith L (2007) Exploring the international linkages of the euro area: a global VAR analysis. J Appl Econ 22:1-38. https://doi.org/10.1002/jae.932

Eickmeier S, Ng T (2015) How do US credit supply shocks propagate internationally? A GVAR approach. Eur Econ Rev 74:128-145. https://doi.org/10.1016/j.euroecorev.2014.11.011

Fratzscher M, Lo Duca M, Straub R (2017) On the international spillovers of US quantitative easing. Econ J 128:330-377. https://doi.org/10.1111/ecoj.12435

Galesi A, Sgherri S (2009) Regional financial spillovers across Europe: a global VAR analysis. IMF working paper, 09/23

Gambacorta L, Hofmann B, Peersman G (2014) The effectiveness of unconventional monetary policy at the zero lower bound: a cross-country analysis. J Money Credit Bank 46:615-642. https://doi.org/10.1111 /jmcb.12119

Ganelli MG, Tawk N (2016) Spillovers from Japan's unconventional monetary policy to emerging Asia: a global VAR approach. International Monetary Fund, working paper, no. 16/99. https://www.imf. org/en/Publications/WP/Issues/2016/12/31/Spillovers-from-Japans-Unconventional-Monetary-Policy-toEmerging-Asia-a-Global-VAR-approach-43913

Georgiadis G (2016) Determinants of global spillovers from US monetary policy. J Int Money Financ 67:4161. https://doi.org/10.1016/j.jimonfin.2015.06.010

Hajek J, Horvath R (2018) International spillovers of (un) conventional monetary policy: the effect of the ECB and the US fed on non-euro EU countries. Econ Syst 42:91-105. https://doi.org/10.1016/j. ecosys.2017.10.001

Hausman J, Wongswan J (2011) Global asset prices and FOMC announcements. J Int Money Financ 30:547571. https://doi.org/10.1016/j.jimonfin.2011.01.008

International Monetary Fund (2005) World economic outlook database, April 2005

Ito T (2017) A new financial order in Asia: will a RMB bloc emerge? J Int Money Financ 74:232-257. https://doi.org/10.1016/j.jimonfin.2017.02.019

Koop G, Pesaran M, Potter S (1996) Impulse response analysis in nonlinear multivariate models. J Econometr 74:119-147. https://doi.org/10.1016/0304-4076(95)01753-4

Krippner L (2016) Documentation for measures of monetary policy. Retrieved from http://www.rbnz.govt.nz//media/ReserveBank/Files/Publications/Research/Additional\%20research/Leo\%20Krippner/5892888. pdf. Accessed 6 Apr 2019

Martin F, Crespo Cuaresma J (2017) Weighting schemes in global VAR modelling: a forecasting exercise. Lett Spat Resour Sci 10:45-56

Mogford C, Pain D (2006) The information content of aggregate data on financial futures positions. Bank Eng Q Bull 46

Neely CJ (2013) Unconventional monetary policy had large international effects. Working paper series 2010018E. Federal Reserve Bank of St. Louis

Ono S (2018) Spillovers of US conventional and unconventional monetary policies to Russian financial markets. Int J Econ Financ 10:14-19. https://doi.org/10.5539/ijef.v10n2p14

Organisation for Economic Co-operation and Development (OECD) (2011) OECD economic surveys: Russian Federation 2011. OECD Publishing, Paris 
Pesaran H, Shin Y (1998) Generalized impulse response analysis in linear multivariate models. Econ Lett 58: 17-29. https://doi.org/10.1016/S0165-1765(97)00214-0

Pesaran M, Schuermann T, Weiner SM (2004) Modeling regional interdependencies using a global errorcorrecting macroeconometric model. J Bus Econ Stat 22:129-162. https://doi.org/10.1198 /073500104000000019

Rogers JH, Scotti C, Wright JH (2014) Evaluating asset-market effects of unconventional monetary policy: a multi-country review. Econ Policy 29:749-799. https://doi.org/10.1111/1468-0327.12042

Sims C (1980) Macroeconomics and reality. Econometrica 48:1-48. https://doi.org/10.2307/1912017

Smith L, Galesi A (2014) GVAR toolbox 2.0. University of Cambridge: Judge Business School

Tillmann P (2016) Unconventional monetary policy and the spillovers to emerging markets. J Int Money Financ 66:136-156. https://doi.org/10.1016/j.jimonfin.2015.12.010

Vansteenkiste I, Hiebert P (2011) Do house price developments spillover across euro area countries? Evidence from a global VAR. J Hous Econ 20(4):299-314. https://doi.org/10.1016/j.jhe.2011.08.003

Wu JC, Xia FD (2016) Measuring the macroeconomic impact of monetary policy at the zero lower bound. J Money Credit Bank 48:253-291. https://doi.org/10.1111/jmcb.12300

Publisher's note Springer Nature remains neutral with regard to jurisdictional claims in published maps and institutional affiliations. 